\title{
A união Paulo Honório $x$ Madalena em São Bernardo: além de um manual de zootecnia
}

\section{Vanderlei da Silva Vicente*}

\begin{abstract}
Resumo: este ensaio pretende abordar as relações sociais do romance São Bernardo, de Graciliano Ramos, analisando de que forma a visão materialista do protagonista Paulo Honório interfere e/ou influencia suas relações humanas, principalmente no que se refere a sua esposa, Madalena. Além disso, também é avaliada a visão do protagonista acerca das questões matrimônio e paternidade.

Palavras-chave: Graciliano Ramos; São Bernardo; relações humanas.
\end{abstract}

\begin{abstract}
: this essay aims at approaching the social relationships in Graciliano Ramos's São Bernardo, analyzing how Paulo Honório's materialistic view interferes and/or influences his human relationships, mainly with his wife, Madalena. Moreover, it is also analyzed the protagonist's view about matrimony and paternity.
\end{abstract}

Keywords: Graciliano Ramos; São Bernardo; human relationships.

O romance São Bernardo, de Graciliano Ramos, tem como um dos pontos centrais as relações humanas explicitadas e vividas pelo personagem-narrador Paulo Honório, ao retomar sua vida através de seu relato-livro. A partir das relações expostas, uma marca torna-se presente nas relações do protagonista, que é o fato de ele comportar-se de uma maneira que pode ser sintetizada em sua própria auto-análise: "A culpa foi minha, ou antes, a culpa foi desta vida agreste, que me deu uma alma agreste.” (RAMOS, 1984, p.101). É assim que Paulo Honório justifica suas ações e/ou reações frente aos fatos marcantes de sua trajetória, de trabalhador braçal despossuído à condição de fazendeiro, intercalada por uma temporada na prisão - o esfaquear um homem teria sido seu primeiro ato "digno de referência" - e tempos como mascate e comerciante de gado.

Visto tal origem, a ascensão social torna-se o norte de Paulo Honório, que não mede esforços para acumular capital e, posteriormente, a fazenda São Bernardo, onde havia trabalhado anos antes. Sua posse se dá com a cobrança de empréstimos feitos a Luís Padilha, herdeiro da fazenda, homem viciado no jogo e na farra. Paulo Honório tem consciência de tudo o que fez para obter as tão sonhadas terras, mas não a certeza da 'nobreza' de tais atos:

\footnotetext{
* Mestrando em Literatura Brasileira no Programa de Pós-Graduação do Instituto de Letras da UFRGS. Professor de literatura em escolas da rede privada de Porto Alegre.
} 
A verdade é que nunca soube quais foram os meus atos bons e quais foram os maus. Fiz coisas boas que me trouxeram prejuízo; fiz coisas ruins que deram lucro. E como sempre tive a intenção de possuir as terras de São Bernardo, considerei legítimas as ações que me levaram a obtê-las. (RAMOS,1984, p.39)

A um homem que lhe devia certa quantia, o personagem foi direto e tão "agreste" como aquele mundo: "Amarrei-o, meti-me com ele na capoeira, estraguei-lhe os couros nos espinhos dos mandacarus, quipás, alastrados e rabos-de-raposa" (RAMOS, 1984, p.14). Frente a uma possível interferência da justiça, Paulo Honório acaba-lhe com as esperanças: "Que justiça! Não há justiça nem religião. O que há é que o senhor vai espichar aqui trinta contos e mais os juros de seis meses. Ou paga ou eu mando sangra-lo devagarinho" (RAMOS, 1984, p.14).

Para João Luiz Lafetá (1984), o personagem vive um processo de reificação, no qual as próprias pessoas tornam-se objetos passíveis de valor:

A reificação é um fenômeno primeiramente econômico: os bens deixam de ser encarados como valores-de-uso e passam a ser vistos como valores-de-troca e, portanto, como mercadorias. Mas sabemos que a consciência humana se forma no contato com a realidade, na atividade transformadora do mundo, que é produção de bens. Assim, as características do modo de produção infiltram-se na consciência que o homem tem do mundo, condicionando seu modo de ver e compondo-lhe, portanto, a personalidade. A reificação abrange então toda a existência, deixa de ser apenas uma componente das forças econômicas e penetra na vida privada dos indivíduos. (LAFETÁ,1984, p.204)

Para Paulo Honório, todos aqueles que viviam, de certa forma, dependentes de sua condição de proprietário deveriam revelar certo "valor-de-troca" para que pudessem ser vistos como uma espécie de investimento válido. LAFETÁ (1984) ainda argumenta que essa obsessão pela reificação impede um olhar "humano" sobre as relações:

Mediada sempre pelo mercado, a consciência humana tende progressivamente a fechar-se à compreensão dos elementos qualitativos e sensíveis da realidade. Todo valor se transforma ilusoriamente - em valor-de-troca. E toda a relação humana se transforma - destruidoramente numa relação entre coisas, entre possuído e possuidor. (LAFETÁ, 1984, p.203)

Esse tipo de relação pode ser identificado entre Paulo Honório e alguns personagens, mas dentre as diversas relações estabelecidas no decorrer da obra, uma, entretanto, chama a atenção: Madalena, a escolhida para ser sua esposa. É com ela que essa relação de "valor-detroca" parece mais se salientar, visto que a própria aproximação entre os dois se deu por uma necessidade de Paulo Honório: a busca de um herdeiro para que todas as suas conquistas materiais tivessem continuidade. O momento no qual o personagem explicita sua decisão de casar-se expõe seu real desejo:

Amanheci um dia pensando em casar. Foi uma idéia que me veio sem que nenhum rabo-desaia a provocasse. Não me ocupo com amores, devem ter notado, e sempre me pareceu que 
mulher é um bicho esquisito, difícil de governar. A que eu conhecia era Rosa do Marciano, muito ordinária. Havia conhecido também a Germana e outras dessa laia. Por elas eu julgava todas. Não me sentia, pois, inclinado para nenhuma: o que sentia era desejo de preparar um herdeiro para as terras de São Bernardo. (RAMOS, 1984, p.59)

A escolha por Madalena se dá, aparentemente, sem justificativa, apenas pelo fato de ela estar disponível. Porém, ela ganha a opção ao invés de outras mulheres como as da laia de Germana; ou mesmo das Mendonça; ou ainda da própria Marcela, filha do dr. Magalhães e inicialmente desejada por Paulo Honório por ser uma "peitaria, um pé-de-rabo, um toitiço". Ou seja, Marcela era uma mulher com o perfil necessário para se enquadrar no mundo de Paulo Honório: o mundo da força, da imposição física. Um mundo "agreste". Todavia, sua escolha se deu pela "miudinha e fraquinha" Madalena.

Paulo Honório sabia que, com ela, até mesmo a aproximação teria que ser diferente, mas segue adiante com seus planos:

Até então meus sentimentos tinham sido simples, rudimentares, não havia razão para ocultá-los a criaturas como a Germana e a Rosa. A essas azunia-se a cantada sem rodeios, e elas não se admiravam, mas uma senhora que vem da escola normal é diferente. (RAMOS, 1984, p.81)

Em certo momento da história, Paulo Honório, após pedir a mão de Madalena em casamento e ouvir dela que deveria haver reciprocidade de sentimentos, argumenta: "Qual reciprocidade! Pieguice. Se o casal for bom, os filhos saem bons; se for ruim, os filhos não prestam. A vontade dos pais não tira nem põe. Conheço o meu manual de zootecnia" (RAMOS, 1984, p.87). Fica explícito que para ele a questão "casamento" tinha como indicativo único a idéia de procriação. Mas por que, então, escolher Madalena e não um 'mulherão' como Marcela? Possivelmente a escolha de Madalena tenha se dado exatamente por aquilo que mais a afastava de seu mundo: a cultura letrada.

Paulo Honório tinha um tino natural para negócios, para a acumulação de bens, mas não possuía o tipo de cultura que Madalena havia conquistado na Escola Normal. Sendo assim, a escolha pela professora pode ser vista como uma tentativa de unir o instinto comercial que ele dominava com a formação acadêmica da escolhida; elementos que propiciariam uma prole perfeita. A lógica exposta acima do pais bons equivalem a filhos bons, uma lógica de caráter naturalista, é colocada em prática pelo personagem na busca daquilo que mais valia para seu ser: um herdeiro. Logo, valeria o risco de se envolver com uma mulher que pertencia a uma esfera intelectual diferente. Ou melhor, superior. Paulo Honório expõe suas esperanças, não se mostrando preocupado com suas diferenças: "A senhora, pelo que mostra e pelas informações que peguei, é sisuda, econômica, sabe onde tem 
as ventas e pode dar uma boa mãe de família" (RAMOS, 1984, p.89); e isso já seria o suficiente para estabelecer e/ou justificar a união dos dois.

Uma explicação pertinente para essa possível lógica de Paulo Honório é o fato de ele estar ciente das mudanças sociais que ocorriam paralelamente à sua ascensão, talvez mesmo percebendo que num momento não muito distante, a cultura formal que estaria presente no herdeiro, através de Madalena, seria uma complementação ao instinto que ele daria ao primogênito. Uma atitude que demonstra o quão ciente está Paulo Honório do mundo, é o de ele adquirir utensílios 'modernos', mesmo não sabendo para o que servem: "Comprei móveis e diversos objetos que entrei a utilizar com receio, outros que ainda hoje não utilizo porque não sei para que servem" (RAMOS, 1984, p.39). A própria iniciativa de diversificar a produção e a compra de maquinário para modernizar São Bernardo também contribui para justificar essa visão. Ainda contribui para essa interpretação a maneira como o personagemnarrador percebe que seu Ribeiro, o guarda-livros da fazenda, havia sido engolido pela mudança dos tempos: "Tenho a impressão que o senhor deixou as pernas debaixo de um automóvel, seu Ribeiro. Por que não andou mais depressa? É o diabo” (RAMOS, 1984, p.38).

Apesar de a união se sacramentar, Paulo Honório tem claro na sua cabeça a sua escala de valores: "Professorinhas de primeiras letras a escola normal fabricava às dúzias. Uma propriedade como S. Bernardo era diferente" (RAMOS, p.115). O papel principal de Madalena seria procriar, contribuindo com seu gene culto na geração do rebento. Sendo assim, seria impossível uma comparação entre ela e a fazenda.

Logo, a falta de sintonia, que Paulo Honório nunca imaginara que pudesse trazer algum problema, passa a atormentá-lo. O caráter humanista de Madalena logo entra em choque com as visões de mundo de Paulo Honório, e, uma semana após o casamento, ocorre a primeira briga: ela defende que seu Ribeiro deveria receber um salário maior, enquanto que Paulo Honório e o próprio funcionário acham justos os seus ganhos. "Um bate-boca oito dias depois do casamento! Mau sinal" (RAMOS, 1984, p.101).

Madalena, em seguida, cobra melhorias na escola da fazenda, até então mero enfeite construído para agradar os governantes. Uma despesa de seis contos em material para a escola faz com que Paulo Honório perca a cabeça e espanque Marciano, após breve contestação deste acerca do ritmo de trabalho na fazenda. A cena é vista e condenada por Madalena. Em contrapartida, Paulo Honório sente-se incomodado com tal cobrança, ainda mais se tratando de um "molambo": 
Fiz aquilo porque achei que devia fazer aquilo. E não estou habituado a justificar-me, está ouvindo? Era o que faltava. Grande acontecimento, três ou quatro muxicões num cabra. Que diabo tem você com o Marciano para estar tão parida por ele? (RAMOS, 1984, p.110)

Essa desconfiança banal é a primeira manifestação desta ordem por parte de Paulo Honório. Sendo assim, tudo leva a crer que a questão do ciúme que posteriormente o marido sentiria fosse fruto muito mais da falta de sintonia entre os interesses e visões do casal do que de uma real possibilidade de traição, visto que esse sentimento acomete o personagem logo após uma crise de valores do casal.

Entretanto, o objetivo inicial da relação dá seu fruto: "Madalena estava prenhe, e eu pegava nela como em louça fina. Ultimamente dizia-me coisas desagradáveis, que eu fingia não compreender. Via a barriga crescer-lhe. Uma compensação" (RAMOS, 1984, p.113). Paulo Honório tenta suportar suas desavenças com a possibilidade do tão sonhado herdeiro e imagina o quão mais fácil seria a 'vida reprodutiva' e/ou 'amorosa' dos animais:

Demorei-me um instante vendo um casal de papa-capins namorando escandalosamente. Uma galinhagem desgraçada. Dentro de alguns dias aquilo se descasava, cada qual tomava seu rumo, sem dar explicações a ninguém. Que sorte!" (RAMOS, 1984, p.120)

A mesma animalização que justifica para o personagem a hereditariedade seduz Paulo Honório, que vislumbra no exemplo das aves o ideal de relação. A procriação teria espaço, sem a necessidade de dar explicações ao cônjuge. Exatamente um dos pontos-fracos do personagem na relação com sua esposa.

Com o passar do tempo, aquilo que era inicialmente uma mera desconfiança ganha força com a proximidade de Madalena e Luís Padilha, o ex-proprietário e agora professor da fazenda. Paulo Honório cobra dele porquê foi visto apanhando flores e conversando com sua esposa:

Isso não é comigo, defendeu-se Luís Padilha. Queixe-se dela. A moça me pediu umas flores para enfeitar a mesa, à tarde. Que é que eu havia de fazer? Havia de negar? E quanto às conversas, seu Paulo compreende. Uma senhora instruída meter-se nestas bibocas! Precisa de uma pessoa com quem possa entreter de vez em quando palestras amenas e variadas. (RAMOS, 1984, p.124)

O ciúme veio em seguida, na forma de uma sensação estranha até mesmo para o próprio personagem: "Mais tarde, no escritório, uma idéia indeterminada saltou-me na cabeça, esteve lá por um instante quebrando a louça e deu o fora. Quando tentei agarrá-la, ia longe" (RAMOS, 1984, p.125). Após este primeiro momento, Paulo Honório chega à conclusão de que as "palestras revolucionárias" de Luís Padilha teriam eco na postura "socialista" de Madalena. Assim, o personagem cria uma espécie de justificativa para explicitar sua angústia frente às diferenças: "Sim senhor! Conluiada com o Padilha e tentando afastar os empregados 
sérios do bom caminho. Sim senhor, comunista! Eu construindo e ela desmanchando" (RAMOS, 1984, p.130). E o ciúme toma o personagem de assalto. Dessa forma, o próprio filho perde o sentido, a ponto de sua existência ser praticamente desprezada ao longo da história. O momento no qual Paulo Honório dá mais referências sobre seu filho é quando ele tenta encontrar semelhanças de outros homens no menino:

Afastava-me, lento ia ver o pequeno, que engatinhava pelos quartos, às quedas, abandonado. Acocorava-me e examinava-o. Era magro. Tinha os cabelos louros, como os da mãe. Olhos agateados. Os meus são escuros. Nariz chato. De ordinário as crianças têm o nariz chato. Interrompia o exame, indeciso: não havia sinais meus; também não havia os de outro homem. (RAMOS, 1984, p.135)

O filho, antes tão desejado, pode tornar-se também um motivo a mais para que sua incapacidade de adequação à visão de mundo de Madalena transforme-se numa suspeita de adultério. E isso era o que Paulo Honório mais queria: a justificação de seus atos.

Um procedimento bastante marcante na relação entre Paulo Honório e sua esposa é o fato de que ele transforma hipóteses em fatos concretos. A partir daí, o personagem passa a agir baseado não mais em suposições, mas sim como se tais fatos fossem reais. A possibilidade de Madalena ser adúltera torna-se realidade, e a infidelidade da esposa, já um fato real para o marido, amplia seu leque de possibilidades, visto que todos aqueles que conviviam com a esposa se tornam amantes potenciais: o advogado João Nogueira, que estava na casa do Dr. Magalhães quando Paulo Honório a vira pela primeira vez; Dr. Magalhães, um "homem idoso!"; Padre Silvestre, que passara por São Bernardo: "Eu fiquei de orelha em pé, desconfiado. Deus me perdoe, desconfiei. Cavalo amarrado também come" (RAMOS, 1984, p.150). O complô se estabelece, visto que ele desconfia que até mesmo a negra Margarida que o criara poderia estar auxiliando Madalena na farsa.

A partir do momento em que Madalena torna-se adúltera, pelo menos na cabeça de Paulo Honório, o marido passa a agredi-la verbalmente. Termos como galinha e cachorra são utilizados por ele em meio a discussões. "Mulher não vai com carrapato porque não sabe qual é o macho" (RAMOS, 1984, p.151). Só faltava uma prova para que a esposa fosse desmascarada. Seguindo a lógica de agir a partir de suposições que se tornam fatos, Paulo Honório passa a acusar sua esposa de forma objetiva e franca. Em certo momento, ele insinua que assobios ouvidos na casa deveriam ser dos seus amantes. O mesmo vale para passos ouvidos na pátio: "São os seus parceiros que andam rondando a casa. Mas não tem dúvida: qualquer dia fica um diabo aí estirado" (RAMOS, 1984, p.152).

No mundo em que Paulo Honório vivia, tal traição deveria ter uma reação tal qual tivera o Jaqueira, homem que era humilhado por todos da região. "Toda a gente dormia com a 
mulher do Jaqueira. Era só empurrar a porta. Se a mulher não abria logo, Jaqueira ia abrir, bocejando e ameaçando: - Um dia mato um peste" (RAMOS, 1984, p.143). E ele realmente matou, ganhando o respeito de todos após passar uma temporada na cadeia. "Nunca mais ninguém buliu com o Jaqueira" (RAMOS, 1984, p.144).

Para Paulo Honório a situação de sua esposa era praticamente idêntica à de Jaqueira, visto que ele pensa em seguir o próprio exemplo "agreste" dado por este personagem ao tratar do adultério de sua esposa.

Essa desconfiança de Paulo Honório também afeta a forma como ele mesmo se via no mundo, pois a partir das "traições", ele passa a sofrer de crises de auto-estima:

Em parte, a culpa era minha: não me tratava. Ocupado com o diabo da lavoura, ficava três, quatro dias sem raspar a cara. E quando voltava do serviço, trazia lama até nos olhos: dêem por visto um porco. Metia-me em água quente, mas não havia esfregação que tirasse aquilo tudo. Que mãos enormes! As palmas eram enormes, gretadas, calosas, duras como casco de cavalo. E os dedos eram também enormes, curtos e grossos. Acariciar uma fêmea com semelhantes mãos! (RAMOS, 1984, p.138)

O ápice da desconfiança se dá quando certo dia Paulo Honório vê a mulher escrevendo uma carta endereçada a Azevedo Gondim. Madalena recusa-se a mostrar o que escrevia, o que foi suficiente para que Paulo Honório tivesse outro acesso de fúria. Aí estava a prova. Pelo menos na sua lógica "agreste", que mais uma vez encontra uma forma de escape de sua incapacidade de conviver com as diferenças entre ele e Madalena. Visto a tentativa de Dona Glória, tia de Madalena, de intervir, o personagem-narrador é direto: "Vá amolar a puta que a pariu. Está mouca, aí com sua carinha de santa? É isto: puta que a pariu. E se achar ruim, rua. A senhora e a boa de sua sobrinha, compreende? Puta que pariu as duas" (RAMOS, 1984, p.139).

O drama da carta ainda aumenta após Paulo Honório encontrar uma página da carta voando pelo pátio. Ele não tem dúvidas de que se tratava de carta a homem e trata de adivinhar termos que para ele eram desconhecidos:

Aquilo era trecho de carta, e de carta a homem. Não estava lá o nome do destinatário, faltava o princípio, mas era carta a homem, sem dúvida. Li a folha pela terceira vez, atordoado, detendome nas expressões claras e procurando adivinhar a significação dos termos obscuros. (RAMOS, 1984, p.157)

A oposição mundo letrado x mundo iletrado ganha força neste momento, pois o caráter "agreste" de Paulo Honório trata de impor-se sobre as letras, no intuito, mais uma vez, de justificar suas ações.

Ao interpelá-la, Madalena mostra-se tranqüila, o que aumenta ainda mais a raiva de Paulo Honório, que vê motivos suficientes para matá-la: “Afirmei a mim mesmo que matá-la 
era ação justa. Para que deixar viva mulher tão cheia de culpa? Quando ela morresse, eu lhe perdoaria os defeitos" (RAMOS, 1984, p.159). Paulo Honório incorpora, com tais idéias, o 'estilo Jaqueira' de ser. Ou seja, uma reação em perfeita sintonia com a sistemática daquele mundo "agreste".

Madalena, a partir dessa nova acusação, começa a comportar-se de uma forma passiva, demonstrando que, de certa forma, havia desistido de viver naquela situação. Ela, então, passa a falar sobre sua morte como algo possível e próximo. Sobre a carta, ela diz que ele logo saberia de toda a verdade.

Seu suicídio ocorre em seguida, assim como a descoberta sobre a carta:

Sobre a banca de Madalena estava o envelope de que ela me havia falado. Abri-o. Era uma carta extensa em que se despedia de mim. Li-a, saltando pedaços e naturalmente compreendendo pela metade, porque topava a cada passo aqueles palavrões que a minha ignorância evita. Faltava uma página: exatamente a que eu trazia na carteira, entre faturas de cimento e orações contra maleitas que a Rosa anos atrás me havia oferecido. (RAMOS, 1984, p.166)

Neste momento, de acordo com LAFETÁ (1984), o personagem parte para uma busca dos significados de sua vida: “Agir, mandar, cultivar S. Bernardo, nada disso terá mais sentido para ele. O mundo desgovernou-se, só lhe resta sentar e buscar, compondo a narrativa de sua vida, o significado de tudo que lhe escapa" (p.207).

Paulo Honório, em sua busca desmedida de acumular capital e perpetuar sua família iniciada por ele mesmo, como Paulo Honório afirma na obra - joga fora sua relação com Madalena. Esse fato desencadeia um processo de reavaliação de sua vida, o projeto de seu livro, que, de acordo com LAFETÁ (1984), seria o início da busca de "valores autênticos":

A verdadeira busca começa onde termina a vida de Paulo Honório. A busca verdadeira, entenda-se, a procura dos verdadeiros e autênticos valores que deveriam reger as relações entre os homens. [...] Antes, Paulo Honório fora um personagem coeso e forte, movendo-se em um mundo de objetivos claros e (ainda que ilusório) repleto de significado: a propriedade. O suicídio de Madalena desmascara a falsidade do sentido e problematiza tudo. Agir para quê? pergunta-se ele. (LAFETÁ, 1984, p.210)

A falência da relação entre Paulo Honório e Madalena expõe a fragilidade de suas convicções acerca da união homem x mulher, que, como foram colocados neste texto, se baseavam na idéia única de procriação, independente das diferenças de valores e/ou visões de mundo. A animalização desejada, baseada em seus manuais de zootecnia, e admirada entre as aves não parece funcionar na sua relação, e o personagem acaba numa grande solidão: "Se ao menos a criança chorasse... nem sequer tenho a amizade a meu filho. Que miséria" (RAMOS, 1984, p.188). 


\section{Referências}

LAFETÁ, Luís. O mundo à revelia. In: RAMOS, Graciliano. São Bernardo. Rio de Janeiro: Record, 1984.

RAMOS, Graciliano. São Bernardo. Rio de Janeiro: Record, 1984. 